Bangladesh J. Plant Taxon. 20(2): 255-257, 2013 (December)

(C) 2013 Bangladesh Association of Plant Taxonomists

- Short communication

\title{
ADDITIONS TO THE ANGIOSPERM FLORA IN THE SITAPAHAR RESERVE FOREST OF KAPTAI, RANGAMATI, BANGLADESH
}

\author{
Mohammad Harun-Ur-Rashid ${ }^{1}$ and Md. Aminul Islam ChOwdhury \\ Department of Botany, University of Chittagong, Chittagong 4331, Bangladesh
}

Keywords: Additional; Angiosperm taxa; Sitapahar Reserve Forest.

Sitapahar Reserve Forest is one of the botanically richest areas of Bangladesh. Sitapahar including Rampahar forming a single forest beat has been declared reserve forest in 1875. It is situated in Kaptai upazila under Rangamati district and is about $60 \mathrm{~km}$ away from Chittagong city (Anonymous, 1970). Sitapahar Reserve Forest is situated approximately between $22^{\circ} 26^{\prime} \mathrm{N}$ and $22^{\circ} 38^{\prime} \mathrm{N}$ latitude and $92^{\circ} 08^{\prime} \mathrm{E}$ and $92^{\circ} 17^{\prime} \mathrm{E}$ longitude. This tropical rain forest occupying approximately 922 acres; the highest peak being about $460 \mathrm{~m}$ above the sea level (Uddin et al., 1998). The under explored hilly forest area represents a rain forest mainly of semi-evergreen type of vegetation at Kaptai Forest Range under the administration of the South Forest Division, Chittagong Hill Tracts. Though the area is very rich in species diversity but a comprehensive floristic study of the area is still lacking. Heinig (1925) listed 45 taxa from the Sitapahar. Later Uddin et al. (1998) recorded 332 species from the area, of which 248 species belong to Magnoliopsida (Dicotyledons) and 84 to Liliopsida (Monocotyledons). This natural forest is under enormous and persistent threats mainly due to different anthropogenic activities. As a result, a number of economically important species as well as germplasm stocks have become endangered or threatened and perhaps extinct of a few. Since Uddin et al. (1998) there has been no comprehensive plant exploration survey in Sitapahar. Therefore, the present work had been undertaken and added 43 taxa under 42 genera belonging to 24 families to the previous accounts of the study area.

The reserve forest has been explored and plant specimens have been collected from the area through repeated extensive explorations during 2010-2011. The identification of specimens has been made with consultation of different Floras and relevant literature e.g. Hooker (1872-1897), Prain (1903), Uddin et al. (1998), Siddiqui et al. (2007) and Ahmed et al. (2008-2009), and consulting properly identified herbarium specimens lodged at the Chittagong University Herbarium (HCU), Bangladesh Forest Research Institute Herbarium (BFRIH), Dhaka University Salar Khan Herbarium (DUSH) and Bangladesh National Herbarium (DACB).

The additional occurrence of 43 angiosperm taxa is presented alphabetically along with their family names, habit and voucher specimens in Table 1. Genera reported for the first time from the study area are indicated with asterisk $(*)$ marks. All collected specimens have been lodged at HCU.

Among the recorded taxa Magnoliopsida (Dicotyledons) is represented by 38 species under 37 genera and 21 families, whereas Liliopsida (Monocotyledons) consists of 5 taxa under 5 genera and 3 families. It is an extend species diversity to the area, exhibits different life forms e.g. 18 herbs, 8 shrubs, 11 climbers and 6 trees. Two families, Apiaceae and Liliaceae, and 21 genera have been reported here for the first time from the area. Populations of four species namely, Byttneria aspera, Phlogacanthus curviflorus, Sterculia balanghas and Syzygium oblatum have been determined to be rarely distributed to the area and facing severe threats at different degrees.

${ }^{1}$ Corresponding author. Email: haruncu@gmail.com 
Table 1. Additional taxa to the Sita Pahar reserve forest.

\begin{tabular}{|c|c|c|c|c|}
\hline Sl. & Taxa & Family & Habit & Voucher \\
\hline & Magnoliopsida & & & \\
\hline 1 & Aglaia perviridis Hiern & Meliaceae & Tree & H 22 \\
\hline 2 & ${ }^{*}$ Aidia oppositifolia (Roxb.) Rahman \& Das & Rubiaceae & Tree & H 212 \\
\hline 3 & Alternanthera philoxeroides (Mart.) Griseb. & Amaranthaceae & Herb & H 130 \\
\hline 4 & Byttneria aspera Colebr. ex Wall. & Sterculiaceae & Climber & H 125 \\
\hline 5 & ${ }^{*}$ Centella asiatica (L.) Urban & Apiaceae & Herb & H 36 \\
\hline 6 & ${ }^{*}$ Cissampelos pareira L. & Menispermaceae & Climber & H 126 \\
\hline 7 & Cissus javana DC. & Vitaceae & Climber & Н 253 \\
\hline 8 & ${ }^{*}$ Codariocalyx gyroides (Roxb. ex Link) Hassk. & Fabaceae & Shrub & H 252 \\
\hline 9 & Combretum griffithii Heurck \& Muell.-Arg. & Combretaceae & Climber & Н 220 \\
\hline 10 & ${ }^{*}$ Crassocephalum crepidioides (Benth.) S. Moore & Asteraceae & Herb & H 105 \\
\hline 11 & ${ }^{*}$ Euphorbia thymifolia L. & Euphorbiaceae & Herb & H 139 \\
\hline 12 & Flemingia involucrata Benth. & Fabaceae & Shrub & H 136 \\
\hline 13 & ${ }^{*}$ Hygrophila polysperma (Roxb.) T. Anders. & Acanthaceae & Herb & Н 01 \\
\hline 14 & ${ }^{*}$ Ipomoea mauritiana Jacq. & Convolvulaceae & Climber & Н 260 \\
\hline 15 & I. pes-tigridis L. & Convolvulaceae & Climber & H 87 \\
\hline 16 & *Justicia japonica Thunb. & Acanthaceae & Herb & H 66 \\
\hline 17 & Lepisanthes senegalensis (Poir.) Leenh. & Sapindaceae & Shrub & H 17 \\
\hline 18 & ${ }^{*}$ Limnophila indica (L.) Druce & Scrophulariaceae & Herb & H 90 \\
\hline 19 & Lindernia crustacea (L.) F. Muell & Scrophulariaceae & Herb & H 77 \\
\hline 20 & Macaranga peltata (Roxb.) Muell.-Arg. & Euphorbiaceae & Tree & H 51 \\
\hline 21 & ${ }^{*}$ Macrosolen cochinchinensis (Lour.) Van Tiegh. & Loranthaceae & Epiphyte & H 123 \\
\hline 22 & ${ }^{*}$ Mecardonia procumbens (Mill.) Small & Scrophulariaceae & Herb & H 76 \\
\hline 23 & Merremia umbellata (L.) Hallier f. & Convolvulaceae & Climber & H 63 \\
\hline 24 & Millettia pachycarpa Benth. & Fabaceae & Climber & H 101 \\
\hline 25 & ${ }^{*}$ Mitracarpus hirtus (L.) DC. & Rubiaceae & Herb & H 194 \\
\hline 26 & Ophiorrhiza mungos L. & Rubiaceae & Herb & Н 213 \\
\hline 27 & Phlogacanthus curviflorus Nees & Acanthaceae & Shrub & H 74 \\
\hline 28 & ${ }^{*}$ Physalis angulata L. & Solanaceae & Herb & H 108 \\
\hline 29 & Polygonum praetermissum Hook. f. & Polygonaceae & Herb & H 02 \\
\hline 30 & Solanum americanum Mill. & Solanaceae & Herb & H 71 \\
\hline 31 & *Sterculia balanghas L. & Sterculiaceae & Tree & H 152 \\
\hline 32 & * Synedrella nodiflora (L.) Gaertn. & Asteraceae & Herb & Н 242 \\
\hline 33 & Syzygium oblatum (Roxb.) Wall. ex Cowan \& Cowan & Myrtaceae & Tree & H 97 \\
\hline 34 & Teramnus labialis (L. f.) Spreng. & Fabaceae & Climber & H 88 \\
\hline 35 & Tetrastigma serrulatum (Roxb.) Planch. & Vitaceae & Climber & H 111 \\
\hline 36 & ${ }^{*}$ Trichosanthes tricuspidata Lour. & Cucurbitaceae & Climber & H 216 \\
\hline 37 & Vitex peduncularis Wall. ex Schauer & Verbenaceae & Tree & H 143 \\
\hline \multirow[t]{2}{*}{38} & ${ }^{*}$ Vitis heyneana Roem. \& Schult. & Vitaceae & Climber & Н 256 \\
\hline & Liliopsida & & & \\
\hline 39 & ${ }^{*}$ Crinum viviparum (Lam.) R. Ansari \& V. J. Nair & Liliaceae & Herb & H 128 \\
\hline 40 & Cyrtococcum patens var. latifolium (Honda) Ohwi & Poaceae & Herb & H 41 \\
\hline 41 & ${ }^{*}$ Didymosperma gracilis Hook. f. & Arecaceae & Tree & H 62 \\
\hline 42 & Saccharum longisetosum (Anders.) Narayan. ex Bor & Poaceae & Herb & H 67 \\
\hline 43 & ${ }^{*}$ Sacciolepis myosuroides (R. Br.) A. Camus & Poaceae & Herb & H 06 \\
\hline
\end{tabular}


The Sitapahar reserve forest is floristically diverse and rich. Due to many anthropogenic activities biodiversity of the forest is in severe threat. Therefore, the following recommendations should be adopted for the sake of better management of the forest and biodiversity: i. natural habitats of biodiversity should be maintained; ii. conservation priorities should be given to the rare, threatened and endangered species; iii. mapping of threatened plants should be prepared to facilitate exact location in the forest; iv. public awareness should be created towards sustainable uses of the biodiversity, particularly the medicinal plants; v. accentuate the monitoring of the conservation activities; vi. in severe cases, both in situ and ex situ conservation measures for particular species may be applied for replicating the population.

\section{Acknowledgements}

We thank the Beat Officer and all the staff of Rampahar - Sitapahar Beat, Kaptai Range, Chittagong Hill Tracts South Forest Division, Rangamati, for their immense co-operation during the field works. Thanks are due to the Director, Bangladesh National Herbarium (DACB), Dhaka, and the Divisional Officer, Forest Botany Division, Bangladesh Forest Research Institute (BFRI), Chittagong, for allowing us to consult the libraries and herbarium specimens and providing us with all the supports and facilities required.

\section{References}

Ahmed, Z.U., Begum, Z.N.T., Hassan, M.A., Khondker, M.M., Kabir, S.M.H., Ahmad, M., Ahmed, A.T.A., Rahman, A.K.A. and Haque, E.U. (Eds). 2008-2009. Encyclopedia of Flora and Fauna of Bangladesh. Vols. 6-10. Angiosperms: Dicotyledons. Asiatic Society of Bangladesh, Dhaka.

Anonymous, 1970. Chittagong Hill Tracts Forest Inventory Survey 1961-63. Kassalong and Rankhiang Reserve Forest (Vols. 1 \& 2). Forestry and Engineering International Ltd. (Forestal), Vancouver, Canada.

Heinig, R.L. 1925. List of Plants of Chittagong Collectorate and Hill Tracts. The Bengal Government Branch Press, Darjeeling, India. pp. 1-89.

Hooker, J.D. 1872-1897. The Flora of British India. Vols. 1-7. Indian Reprint 1973. Bishen Singh Mahendra Pal Singh, Dehradun, India.

Prain, D. 1903. Bengal Plants. Vols. 1 \& 2. Indian Reprint 1981. Botanical Survey of India, Calcutta.

Siddiqui, K.U., Islam, M.A., Ahmed, Z.U., Begum, Z.N.T., Hassan, M.A., Khondker, M., Rahman, M.M., Kabir, S.M.H., Ahmad, M., Ahmed, A.T.A., Rahman, A.K.T. and Haque, E.U. (Eds). 2007. Encyclopedia of Flora and Fauna of Bangladesh. Vol. 11. Asiatic Society of Bangladesh, Dhaka. pp. 1-399.

Uddin, S.N., Khan, M.S., Hassan, M.A. and Alam, M.K. 1998. An annotated checklist of angiospermic flora of Sitapahar at Kaptai in Bangladesh. Bangladesh J. Plant Taxon. 5(1): 13-46.

(Manuscript received on 7 April 2013; revised on 2 August 2013) 